\title{
ESTIMATION OF BARE SOIL MOISTURE FROM REMOTE SENSING INDICES IN THE 0.4-2.5 MM SPECTRAL RANGE
}

\author{
Kubiak Katarzyna* (D) 0000-0002-4156-3139 \\ Stypułkowska Justyna (D) 0000-0002-8601-4483 \\ Szymański Jakub (i) 0000-0002-2899-740X \\ Spiralski Marcin (D) 0000-0003-2147-2026 \\ Łukasiewicz Research Network - Institute of Aviation, al. Krakowska 110/114, 02-256 Warsaw, Poland \\ *Katarzyna.Kubiak@ilot.lukasiewicz.gov.pl
}

\begin{abstract}
Soil moisture content (SMC) is an important element of the environment, influencing water availability for plants and atmospheric parameters, and its monitoring is important for predicting floods or droughts and for weather and climate modeling. Optical methods for measuring soil moisture use spectral reflection analysis in the 350-2500 nm range. Remote sensing is considered to be an effective tool for monitoring soil parameters over large areas and to be more cost effective than in situ measurements. The aim of this study was to assess the SMC of bare soil on the basis of hyperspectral data from the ASD FieldSpec $4 \mathrm{Hi}$-Res field spectrometer by determining remote sensing indices and visualization based on multispectral data obtained from UAVs. Remote sensing measurements were validated on the basis of field humidity measurements with the HH2 Moisture Meter and ML3 ThetaProbe Soil Moisture Sensor. A strong correlation between terrestrial and remote sensing data was observed for 7 out of 11 selected indexes and the determination coefficient $\mathrm{R}^{2}$ values ranged from $67 \%$ $87 \%$. The best results were obtained for the NINSON index, with determination coefficient values of $87 \%$, NSMI index $(83.5 \%)$ and NINSOL (81.7\%). We conclude that both hyperspectral and multispectral remote sensing data of bare soil moisture are valuable, providing good temporal and spatial resolution of soil moisture distribution in local areas, which is important for monitoring and forecasting local changes in climate.
\end{abstract}

Keywords: soil moisture content, remote sensing, hyperspectral data, bare soil, UAV.

Type of the work: Research Article

\section{INTRODUCTION}

Soil moisture content (SMC) is an important attribute influencing the availability of water to plants and a key variable in the water and thermal energy exchange cycle between the Earth's surface and atmosphere through evaporation [1], [2]. As constant measurement and monitoring of this parameter plays an important role in various studies - such as estimating and predicting evapotranspiration of plants, analyzing atmospheric parameters, predicting floods or droughts, and weather and climate modeling - it is important to monitor bare soils at various spatial scales [1], [3]. Manual SMC 
measurement methods are based on field studies, often on a local scale, requiring a lot of manpower and resources, so they are difficult to apply across large areas [1], [4]. Remote sensing (RS), on the other hand, is considered to be an effective tool for monitoring soil parameters over large areas and is believed to be more cost effective than in situ measurements [3], [5]. Various studies have been carried out in recent years, based on RS methods to estimate bare SMC with better temporal and spatial coverage [1], [6]. These methods can be divided into four groups: (i) optical methods, (ii) thermal infrared methods, (ii) microwave methods and (iv) synergistic methods. In addition to remote sensing methods, statistical methods (traditional regression techniques) and machine learning techniques are used to estimate soil SMC [1], [6], [7].

Optical methods use spectral reflectance analysis from 350 to $2500 \mathrm{~nm}$ for measuring bare SMC [1], [6]. Examples mainly include methods for the determination and analysis of single SMC indicators based on the near infrared and short-wave infrared (SWIR) bands [8]. SMC can be estimated using thermal methods for estimating thermal inertia and the Earth's Surface Temperature Index (LST) in thermal bands [9]. In recent years, with high spatial resolution, significant success in determining SM has been achieved through the use of microwave RS methods. This is due to the high sensitivity of the backscattered signal to the dielectric constant of the soil and its humidity [2], [10] supplemented with the soil penetration capacity. In this method, the quality of soil moisture determination largely depends on the roughness of the surface [2], [10]. Synergistic methods estimate SMC by combining data from multiple types of remote sensing [6]: for example, optical and thermal infrared, active and passive microwave, microwaves and thermal infrared, or optical and microwave [1].

The trapezoidal method, based on thermal and optical data on the Earth's surface, is very popular. However, this methodology has the disadvantage that the surface temperature of the land is influenced by the surrounding parameters, while the optical reflectance is not. In the design of some indices, it was proposed to use optical observations to monitor soil moisture and drought based on triangular spaces, with pixel distributions of optical observations in various electromagnetic frequency bands (drought monitoring based on triangular spaces from pixel distributions of optical observations in different electromagnetic frequency bands). One of these triangular indices is the PDI (Perpendicular Drought Index), designed by Ghulam et al. [11], [12].

The optical approach is a popular remote sensing method of SMC estimation, mainly due to the possibility of obtaining SMC maps with a higher spatial resolution compared to the microwave method [1], [13]. In recent years, many optical, physical models for remote sensing soil moisture have also been developed [14].

In practice, soil reflectance depends on many factors such as soil type, organic matter, texture, porosity, vegetation cover, mineral composition and color of soil elements [1], [3]. Therefore, a normalized form of transforming two or more spectral reflections, such as SMC indexes, may be easier and more suitable for high resolution remote sensing SMC mapping.

Characteristic fragments of the electromagnetic spectrum are located in the so-called water absorption bands: two in the near infrared bands - close to 960 and $1100 \mathrm{~nm}$, and three in the near infrared: close to 1450,1900 and $2500 \mathrm{~nm}$ [1], [15]. Bowers and Smith reported that the absorption amplitude is linear in the SMC in the water absorption bands [16]. Later studies indicated that the relative estimation of SMC in the shortwave infrared (SWIR) domain (1.4-2.5 $\mu \mathrm{m}$ ) was more efficient [1], [2]. According to the literature data, for the estimation of SMC, the best results were obtained with the following spectral indexes: soil water index WISOIL [17], NSMI [18], NINSOL [2], NINSON [2], NSDI 1, 2, 3 [1], NMDI (Normalized Multi-band Drought Index [3], NDWI Normalized Difference Water Index [3], VSDI (Visible and Shortwave Infrared Drought Index) [19]. These indices consist mainly of shortwave infrared bands and show higher saturation in the SMC assessment. 
The aim of the present study is to estimate the SMC of bare soil on the basis of hyperspectral data from a field spectrometer and multispectral data obtained from UAVs, and to validate those estimates using field measurements of relative electric permeability.

\section{METHODOLOGY}

Soil moisture measurements were taken on 24 November 2020, in the municipality of Borowiec (Tarczyn, Mazowieckie Province) on arable land prepared for new planting of fruit trees. Quantitative analysis of soil texture in the field showed that loamy sand was predominant at the measuring points. The surface vegetation cover was poor (Fig. 1). The field is at the location with the given GPS coordinates: 51.98332 latitude; 20.72525 longitude; altitude of $167 \mathrm{~m}$ AMSL. Moisture measurements were taken at fixed measuring points on the basis of a grid uniformly covering the entire field (Fig. 1). Points of bare soil with no organic residues were chosen. The grid pattern was as is commonly used in soil sampling $[20,21]$. The average distance between the points in a row was $27.24 \mathrm{~m}$, while the average distance between the nearest 4-5 points was $12.13 \mathrm{~m}$.
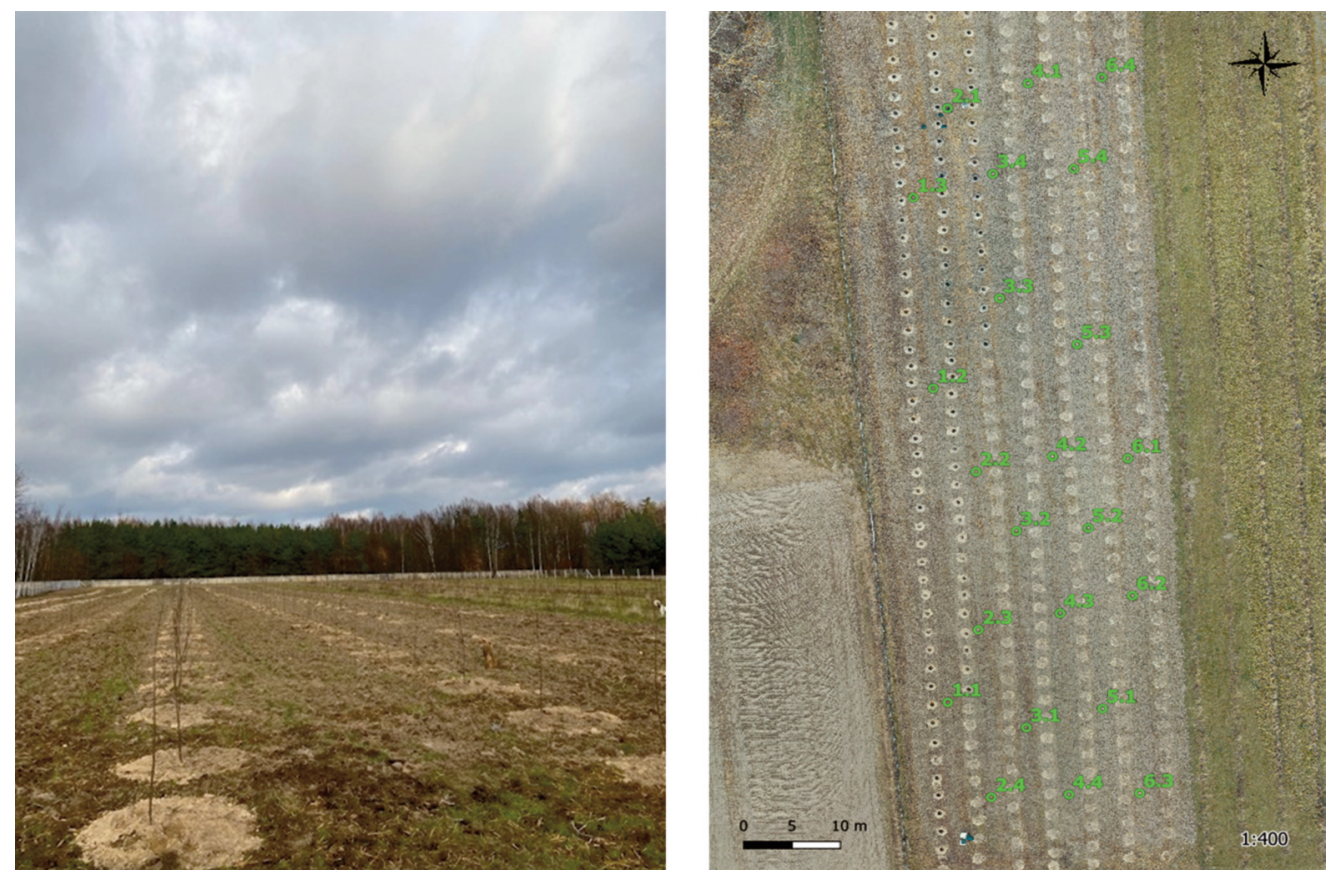

Fig. 1. Arable land prepared for planting fruit trees (left), map of the study area with measurement points marked (right).

The moisture content of the bare soil was measured at the control points in the study area with a field moisture hygrometer - HH2 Moisture Meter with ML3 ThetaProbe (Delta-T Devices, UK) - to a depth of $5 \mathrm{~cm}, 5$ times in each point. At the same points, the spectral signatures of the soil were measured with an ASD FieldSpec $4 \mathrm{Hi}$-Res (Malvern Panalytical, UK) field spectrometer, again 5 times at each point. Terrestrial and hyperspectral measurements were carried out at intervals of about 1 minute. Hyperspectral data was used to determine remote sensing indicators (Tab. 1). 
Tab. 1. RS indices used in the analysis.

\begin{tabular}{|c|c|c|}
\hline Index & Formula & References: \\
\hline WISOIL & $\frac{\mathrm{B}_{1450}}{\mathrm{~B}_{1300}}$ & {$[1]$} \\
\hline NSMI & $\frac{\mathrm{B}_{1800}-\mathrm{B}_{2119}}{\mathrm{~B}_{1800}-\mathrm{B}_{2119}}$ & {$[1]$} \\
\hline NINSOL & $\frac{\mathrm{B}_{2076}-\mathrm{B}_{2230}}{\mathrm{~B}_{2076}-\mathrm{B}_{2230}}$ & {$[1]$} \\
\hline NINSON & $\frac{\mathrm{B}_{2122}-\mathrm{B}_{2230}}{\mathrm{~B}_{2122}-\mathrm{B}_{2230}}$ & {$[1]$} \\
\hline NSDSI1 & $\frac{\mathrm{B}_{1550-1750}-\mathrm{B}_{2100-2300}}{\mathrm{~B}_{1550-1750}}$ & {$[1]$} \\
\hline NSDSI2 & $\frac{\mathrm{B}_{1550-1750}-\mathrm{B}_{2100-2300}}{\mathrm{~B}_{2100-2300}}$ & {$[1]$} \\
\hline NSDSI3 & $\frac{\mathrm{B}_{1550-1750}-\mathrm{B}_{2100-2300}}{\mathrm{~B}_{1550-1750}+\mathrm{B}_{2100-2300}}$ & {$[3]$} \\
\hline NMDI & $\frac{\mathrm{B}_{860}-\mathrm{B}_{1640-2130}}{\mathrm{~B}_{860}+\mathrm{B}_{1640-2130}}$ & {$[3]$} \\
\hline NDWI & $\frac{\mathrm{B}_{841-876}-\mathrm{B}_{1628-1652}}{\mathrm{~B}_{841-876}+\mathrm{B}_{1628-1652}}$ & {$[3]$} \\
\hline VSDI & $1-\left(\mathrm{B}_{1570-1650}-\mathrm{B}_{450-510}+\mathrm{B}_{640-670}+\mathrm{B}_{450-510}\right)$ & {$[3] \mathrm{B}_{841-876}-\mathrm{B}_{640-670)} w i t h$} \\
\hline
\end{tabular}

In addition to the in-situ moisture measurements and spectral curves, aerial imagery was acquired using a Phantom 4 Pro (Da-Jiang Innovations, China) and a Parrot Sequioa multispectral camera (Parrot, France). The photogrammetric flight was taken at an attitude of $70 \mathrm{~m} \mathrm{AGL}$, with flight velocity of $3 \mathrm{~m} / \mathrm{s}$. Two datasets were acquired - a very high resolution RGB orthomosaic ( $2 \mathrm{~cm}$ Ground Sampling Distance - GSD) and a multispectral orthomosaic (5 cm GSD, 4 bands - $550 \mathrm{~nm}, 660 \mathrm{~nm}, 735 \mathrm{~nm}, 790 \mathrm{~nm}$ ). The area covered by the photogrammetric flight was 2 ha. The photographs exhibited $80 \%$ side overlap and $85 \%$ front overlap. Image parameters (such as shutter speed) were determined by the information from the sun sensor integrated with the camera. The DEM (Digital Elevation Model) and DSM (Digital Surface Model) were calculated as well. Values of altitude AMSL were used for correlation with interpolated SMC content. No significant correlation for the research area was found. Multispectral imagery was used for calculating remote sensing indices (calculable from the Parrot Sequioa bands) and their visualization (Fig. 3). For statistical analysis, both humidity data from the field measurements and remote sensing indicators from hyperspectral data were used, the normality of the statistical distribution was checked, and the coefficient of determination $\left(\mathrm{R}^{2}\right)$ and Standard Deviation were determined (Tab. 1). 


\section{RESULTS}

The obtained hyperspectral data clearly show a strong relationship between the course and shape of the spectral signatures and soil moisture content. Exemplary mean signatures (hyperspectral data) from terrestrial spectroradiometer for selected soil moisture values are presented in Figure 2. As is shown, the lower the water content in the soil, the greater the spectral reflection of the soil and the spectral curve takes on higher values, at the same time changing its shape to a flatter one, and lower slopes are visible in the bands around 1400 and $1900 \mathrm{~nm}$. The shape differences are observed in so-called water absorption bands in around 1400-1450 nm, in around $1900 \mathrm{~nm}$ and also in around 2100-2200 nm (Fig. 2). Also, a spectral range between 1600 and $1650 \mathrm{~nm}$ is commonly used for moisture determination, due to its lower sensitivity to vapor content. From hyperspectral data, the mean values of the remote sensing indices, coefficient of determination $\left(\mathrm{R}^{2}\right)$ and Standard Deviation (SD) between the field measurements of soil moisture content and remote sensing indicators were estimated and the results are presented in Table 2.

A strong correlation between terrestrial and remote sensing data was observed for 7 out of 11 selected indexes and the determination coefficient values ranged from $67 \%-87 \%$. The highest results were obtained for NSMI (83.5\%) and NINSOL (81.7\%) indexes, while the best correlation between remote sensing data and ground measurements was visible for the NINSON index with a coefficient of $87 \%$. A low level of correlation between remote sensing indicators and field measurements was observed for VSDI indicators (45\%), NMDI (34\%), NDWI (0.55\%) and SAVI (3.8\%) (Tab. 2).

One of the indicators, SAVI, was visualized on the basis of images from the multispectral camera. SAVI was calculated based on the bands acquired from Parrot Sequoia. The resulting map of the distribution of the values of the selected indicator is shown in figure 3. SAVI values were lower in the eastern part of the research area, a fact that partly corresponded to the SMC values. SAVI results varied longitudinally, whereas the SMC interpolated isolines were more irregular. SAVI acquired from multispectral imagery was consistent with the results from the spectroradiometer.

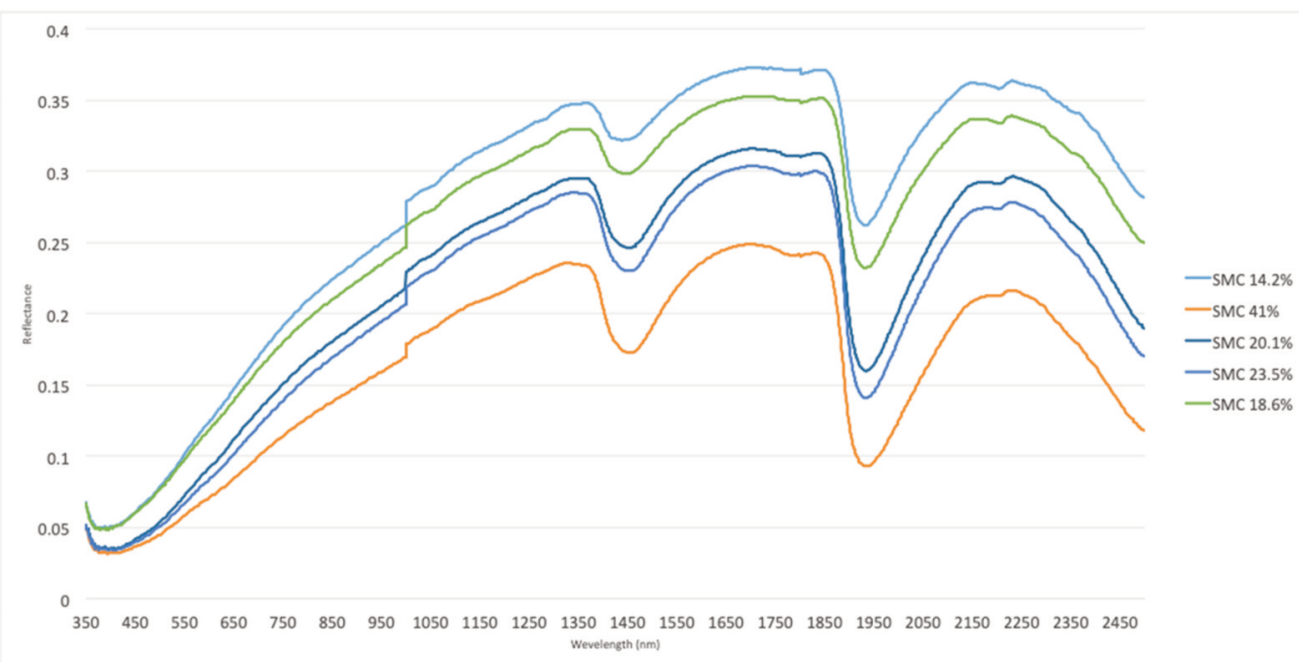

Fig. 2. Selected spectral signatures according to SMC (Soil Moisture Content) (in \%) for a measurement point in the study area. 

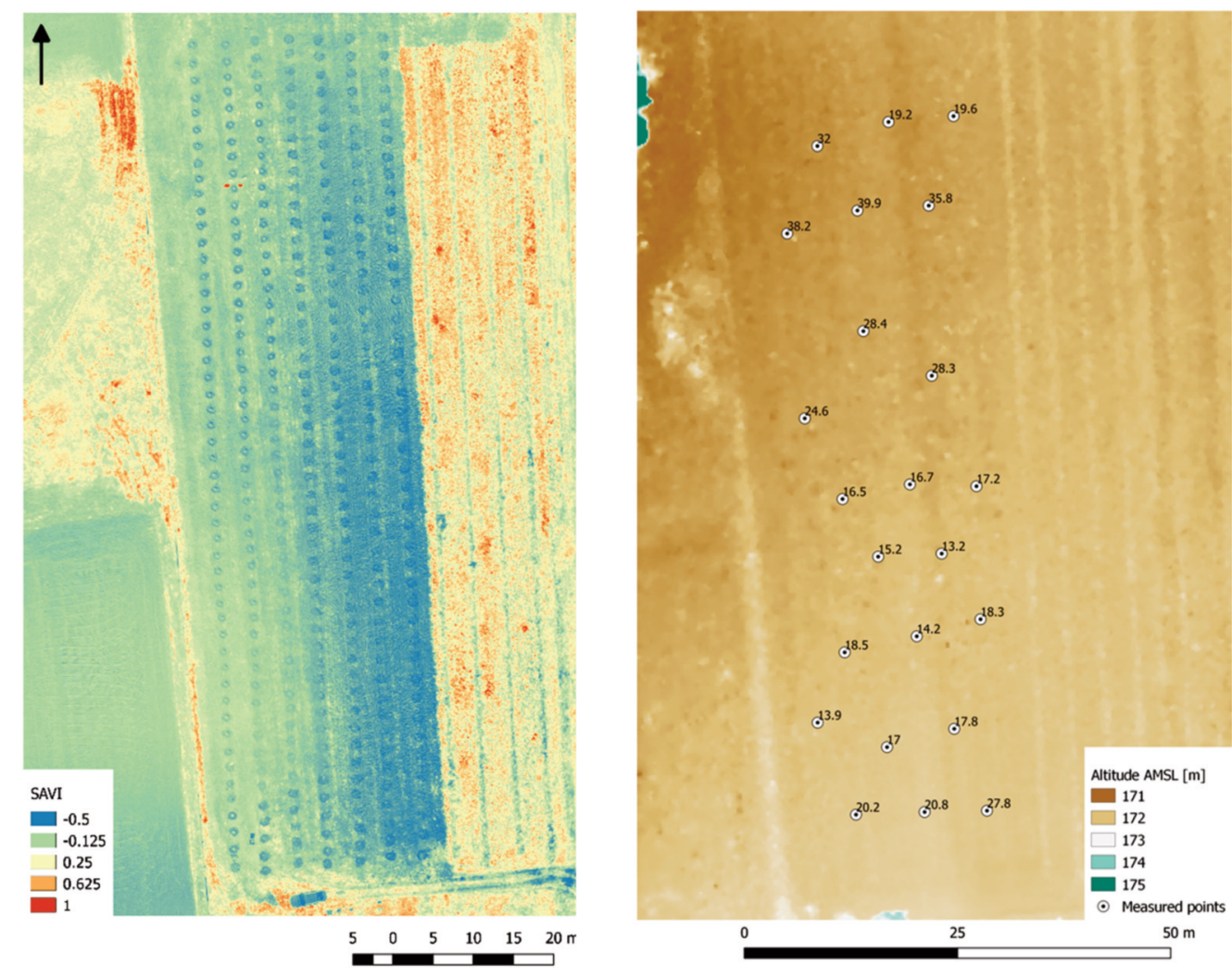

Fig. 3 Distribution of SAVI index values across study area based on aerial remote sensing data from multispectral camera (left) and DEM model with SMC values at measuring points.

Tab. 2. Coefficient of determination $\left(\mathrm{R}^{2}\right)$ for remote sensing indicators and field measurements using terrestrial hyperspectral data.

\begin{tabular}{|c|c|c|c|c|c|c|c|c|c|c|c|}
\hline Index & NDSI1 & NDSM2 & NDSN3 & WISOIL & NSMI & NINSOL & NINSON & VSDI & NMDI & NDWI & SAVI \\
\hline $\mathrm{R}^{2}$ & $66.81 \%$ & $72.74 \%$ & $69.69 \%$ & $72.55 \%$ & $83.52 \%$ & $81.71 \%$ & $86.68 \%$ & $44.62 \%$ & $34.25 \%$ & $0.55 \%$ & $3.81 \%$ \\
\hline $\mathrm{SD}$ & $5.01 \%$ & $6.60 \%$ & $2.85 \%$ & $7.49 \%$ & $3.20 \%$ & $2.75 \%$ & $1.26 \%$ & $13.80 \%$ & $16.58 \%$ & $11.14 \%$ & $11.00 \%$ \\
\hline
\end{tabular}

\section{DISCUSSION}

This study demonstrated the potential of hyperspectral approaches to estimating SMC over bare soil. Differences in spectral signatures depending on water moisture content were clearly observed in so-called water absorption bands in the spectral range around $1450 \mathrm{~nm}$ and at around $1900 \mathrm{~nm}$, which is consistent with data in the literature $[1,15]$. Also, the spectral range between 1600 and $1650 \mathrm{~nm}$ is used commonly in literature for moisture assessment. These bands are often used for RS indices related to moisture content, such as NDWI. However, they are good for characterizing soil water in laboratory measurements or field spectrometer measurements, but are not recommended for air or satellite remote sensing, as these spectral ranges are affected by atmospheric water vapor [23]. Therefore, remote sensing indices are based 
not only on these bands, but also on other fragments of spectral curves which previous research has shown to be sensitive to the water content in the soil (Tab. 1).

In our study, the best results were obtained for the NINSON index $\left(\mathrm{R}^{2}=87 \%, \mathrm{SD}=1.26 \%\right)$ and NSMI index $\left(\mathrm{R}^{2}=84 \%, \mathrm{SD}=3.2 \%\right)$, showing the lowest values of standard deviations. Good results were also obtained for NINSOL $\left(\mathrm{R}^{2}=82 \%, \mathrm{SD}=2.75 \%\right)$. These findings are coherent with previous results. Fabre et al. [2], who tested 32 soil samples and a base consisting of 190 spectral signatures of soil with different moisture content, compared the effectiveness of moisture assessment by the NSMI, NONSON, and NINSOL remote sensing coefficients and obtained the best match scores for NINSOL $\left(\mathrm{R}^{2}=87 \%\right)$ and NINSON $\left(\mathrm{R}^{2}=85 \%\right)$, i.e. approaching $90 \%$, but lower scores for NSMi $\left(\mathrm{R}^{2}=73 \%\right)$. However, the standard errors were higher in their study, at about $20 \%$ for all indexes. Oltra-Carrió et al. [8], studied 323 spectral reflectances of bare soil acquired from hyperspectral data recorded by a FieldSpec spectroradiometer and confirmed the great effectiveness of using NINSON and NINSOL from remote sensing data for estimating soil moisture, showing the sensitivity of both of these indicators to the content of clay in the soil.

In our study, good results were observed for the WISOIL index $\left(\mathrm{R}^{2}=73 \%, \mathrm{SD}=7.49 \%\right)$, which is slightly lower but similar to the value obtained by [24], who obtained, using a laboratory ASD FieldSpecPro spectroradiometer, spectral signatures from 25 soil samples with different textures and varying degrees of moisture content (six SMC levels for each sample, i.e. 0\%, 12\%, 16\%, 21\%, 26\% and 30\%). Based on data from 150 spectral reflectance, they reported the result for the WISOIL index at $\mathrm{R}^{2}=81 \%$ [24]. Study [2] also confirms our results in this respect, showing a high efficiency of the WILSOIL index for estimating soil moisture from hyperspectral dat ( $\mathrm{R}^{2}$ for WILSOIL at $79 \%$ ), albeit with error within $20 \%$ whereas our error was $7.5 \%$.

The following values were obtained for the NDSI index: $\mathrm{R}^{2}=66.81 \%$ with SD $=5.01 \%$ for NDSI 1 , $\mathrm{R} 2=72.74 \%$ with $\mathrm{SD}=6.60 \%$ for NDSI2, R2 $=69.69 \%$ with $\mathrm{SD}=2.85 \%$ for NDSI3. Study [1] proposed these three indicators for studying bare soil moisture from satellite data obtained from Sentinel2 MSI Images and obtained an $\mathrm{R}^{2}$ coefficient for all three indicators within $80-83 \%$, with root mean square error within $8.2-8.8 \%$. This is slightly higher than the results obtained in our study, but still corroborates well with the results obtained in this paper. Li et al. [25] used hyperspectral data and remote sensing indices, e.g. the NDSI index for monitoring moisture in saline soils on the Jiangsu coast with determination coefficient results in the range $78-86 \%$, also confirming the effectiveness of remote sensing optical methods for estimating soil moisture [25].

Aerial imagery is often used for extrapolation and correlation of fieldwork datasets [26]-[29]. Soil samples or soil parameter measurements can correlate well with such data [30]. Roughness [31], texture [32], moisture [30] or nutrient levels [33] can be calculated from both RGB and multispectral imagery acquired from UAVs. Data processing results in Digital Elevation Model (DEMs), Digital Surface Models (DSMs), point clouds and orthophotomaps. Such data can be processed by means of GIS software [34], statistical analysis [30], ML algorithms [35] or object-based classification software [36].

Our research has confirmed the usefulness of a small multispectral camera and a drone for obtaining such data. In our study, the only indicator that could be visualized from a multispectral camera was SAVI, which showed very low values due to the fact that there was very poor vegetation cover on the study area. SAVI is an indicator that was previously used to predicting soil moisture retention properties [37]. On the other hand, [12] tested several remote sensing indicators (including SAVI) to determine moisture on bare soil, pasture and farmland and obtained values for SAVI very similar to our results. SAVI on such a surface showed values close to 0 or negative; the authors concluded that SAVI can only be used when there is a significant correlation to estimate soil moisture in bare soil. Importantly, in our study, on the basis of the SAVI value, it was possible to create a mapping of changes (Fig. 3) in soil moisture, which is related to, for example, soil composition and vegetation cover. 
Observations based on remote sensing of bare soil moisture from hyper- and multispectral remote sensing are of great value, as they provide high temporal and spatial resolution of soil moisture in small areas (up to $100 \mathrm{ha}$ ). In sum, there is a real need to define remote sensing methods using hyperspectral measurements, without prior calibration against laboratory measurements of specific samples taken in the analyzed area, and thus without the need to perform in situ SMC measurements.

\section{CONLCUSIONS}

1. Ground-based hyperspectral data have a good potential for moisture soil content estimation and the best results were achieved with NINSON, NINSOL and NSMI indices.

2. The potential of soil mapping by means of multispectral data has been confirmed widely in the literature. Even though our study was focused on hyperspectral ground measurements, it confirmed the possibility of using specific NIR and SWIR bands for soil mapping purposes. Further investigation should be supplemented by SWIR imagery data, as well as with more advanced processing methods including Machine Learning (ML) techniques.

3. We conclude that both hyperspatial and multispectral remote sensing data of bare soil moisture are valuable, providing good temporal and spatial resolution of soil moisture distribution in local areas, which is important for monitoring and forecasting local changes in climate.

\section{REFERENCES}

[1] Yue, J., Tian, J., Tian, Q., Xu, K. and Xu, N., 2019, "Development of soil moisture indices from differences in water absorption between shortwave-infrared bands," ISPRS J. Photogramm. Remote Sens., 154, 216-230. DOI: 10.1016/j.isprsjprs.2019.06.012.

[2] Fabre, S., Briottet, X. and Lesaignoux, A., 2015, "Estimation of soil moisture content from the spectral reflectance of bare soils in the 0.4-2.5 $\mu \mathrm{m}$ domain," Sensors (Switzerland), 15(2), 32623281. DOI: $10.3390 / \mathrm{s} 150203262$.

[3] Gholami Bidkhani, N.O. and Mobasheri, M. R., 2018, "Influence of soil texture on the estimation of bare soil moisture content using MODIS images," Eur. J. Remote Sens., 51(1), 911-920. DOI: 10.1080/22797254.2018.1514986.

[4] Susha Lekshmi, S. U., Singh, D. N. and Shojaei Baghini, M., 2014, "A critical review of soil moisture measurement," Measurement: Journal of the International Measurement Confederation, (54), 92-105. DOI: 10.1016/j.measurement.2014.04.007.

[5] Wagner, W., Lemoine, G. and Rott, H., 1999, "A method for estimating soil moisture from ERS Scatterometer and soil data," Remote Sens. Environ., 70(2), 191-207. DOI: 10.1016/S00344257(99)00036-X.

[6] Zhang, D. and Zhou, G., 2016, "Estimation of soil moisture from optical and thermal remote sensing: A review," Sensors (Switzerland), 16(8). MDPI AG. DOI: 10.3390/s16081308.

[7] Zhang, C., Mishra, D. R. and Pennings, S. C., 2019 "Mapping salt marsh soil properties using imaging spectroscopy,” ISPRS J. Photogramm. Remote Sens., 148, 221-234.

DOI: 10.1016/j.isprsjprs.2019.01.006.

[8] Oltra-Carrió, R., Baup, F., Fabre, S., Fieuzal, R. and Briottet, X., 2015, "Improvement of Soil Moisture Retrieval from Hyperspectral VNIR-SWIR Data Using Clay Content Information: From Laboratory to Field Experiments,” Remote Sens., 7(3), 3184-3205. DOI: 10.3390/rs70303184.

[9] Gillies, R. R., Carlson, T. N., Cui, J., Kustas, W. P. and Humes, K. S., 1997, "A verification of the 'triangle' method for obtaining surface soil water content and energy fluxes from remote measurements of the normalized difference vegetation index (ndvi) and surface e," Int. J. Remote Sens., 18(15), 3145-3166. DOI: 10.1080/014311697217026. 
[10] Shi, J., Wang, J., Hsu, A. Y., O’Neill, P. E. and Engman, E. T., 1997, “Estimation of bare surface soil moisture and surface roughness parameter using L-band SAR image data," IEEE Trans. Geosci. Remote Sens., 35(5), 1254-1266. DOI: 10.1109/36.628792.

[11] Ghulam, A., Qin, Q., Teyip, T. and Li, Z. I., 2007, "Modified perpendicular drought index (MPDI): a real-time drought monitoring method,” ISPRS J. Photogramm. Remote Sens., 62(2), 150-164. DOI: 10.1016/j.isprsjprs.2007.03.002.

[12] Casamitjana, M., Torres-Madroñero, M. C., Bernal-Riobo, J. and Varga, D., 2020, "Soil Moisture Analysis by Means of Multispectral Images According to Land Use and Spatial Resolution on Andosols in the Colombian Andes," Appl. Sci., 10(16), 5540-5555. DOI: 10.3390/app10165540.

[13] Wang, J., Ling, Z., Wang, Y. and Zeng, H., 2016, "Improving spatial representation of soil moisture by integration of microwave observations and the temperature-vegetation-drought index derived from MODIS products,” ISPRS J. Photogramm. Remote Sens., 113, 144-154.

DOI: 10.1016/j.isprsjprs.2016.01.009.

[14] Bablet, A. et al., 2018, "MARMIT: A multilayer radiative transfer model of soil reflectance to estimate surface soil moisture content in the solar domain (400-2500 nm)," Remote Sens. Environ., 217, 1-17. DOI: 10.1016/j.rse.2018.07.031.

[15] Mohamed, E. S., Saleh, A. M., Belal, A. B. and Gad, A. A., 2018, "Application of near-infrared reflectance for quantitative assessment of soil properties," Egyptian Journal of Remote Sensing and Space Science, 21(1), 1-14. DOI: 10.1016/j.ejrs.2017.02.001.

[16] Bowers, S. A. and Smith, S. J., 1972, "Spectrophotometric Determination of Soil Water Content," Soil Sci. Soc. Am. J., 36(6), pp. 978-980. DOI: 10.2136/sssaj1972.03615995003600060045x.

[17] Whalley, W. R., Leeds-Harrison, P. B. and Bowman, G. E., 1991, "Estimation of soil moisture status using near infrared reflectance," Hydrol. Process., 5(3), 321-327.

DOI: 10.1002/hyp.3360050312.

[18] Haubrock, S. N., Chabrillat, S., Lemmnitz, C. and Kaufmann, H., 2008, "Surface soil moisture quantification models from reflectance data under field conditions," Int. J. Remote Sens., 29(1), 3-29. DOI: 10.1080/01431160701294695.

[19] Zhang, N., Hong, Y., Qin, Q. and Liu, L., 2013, "VSDI: A visible and shortwave infrared drought index for monitoring soil and vegetation moisture based on optical remote sensing," Int. J. Remote Sens., 34(13), 4585-4609. DOI: 10.1080/01431161.2013.779046.

[20] Knowles, O. and Dawson A., 2018, "Current soil sampling methods - a review", in: Farm environmental planning - Science, policy and practice. (L.D. Currie and C.L. Christensen, Eds), Occasional Report No. 31, Fertilizer and Lime Research Centre, Massey University, Palmerston North, New Zealand.

[21] Scrimgeour, C., 2008, "Soil Sampling and Methods of Analysis", in: Experimental Agriculture, M.R. Carter and E.G. Gregorich, Eds, Boca Raton, Fl, USA: CRC Press, 44(3).

DOI: $10.1017 /$ S0014479708006546.

[22] Chen, J. M., 1996, "Evaluation of vegetation indices and a modified simple ratio for boreal applications," Can. J. Remote Sens., 22(3), 229-242. DOI: 10.1080/07038992.1996.10855178.

[23] Gomez, C. and Lagacherie, P., 2016, "Mapping of Primary Soil Properties Using Optical Visible and Near Infrared (Vis-NIR) Remote Sensing", in "Land Surface Remote Sensing in Agriculture and Forest", Nicolas Baghdadi, Mehrez Zribi, Eds, Elsevier, 1-35.

[24] Ansari, S., Padmanabhi, A. D. and Deshmukh, D. R. R., 2017, "Spectral Estimation of Soil Moisture Content using Semi Empirical Soil Model in the 0.4-2.5 $\mu \mathrm{m}$ Domain,” Int. J. Comput. Appl. Technol. Res., 6(07), 338-343. DOI: 10.7753/ijcatr0607.1013.

[25] Li, C. et al., 2016, "Hyperspectral parameters and prediction model of soil moisture in coastal saline," Chinese J. Appl. Ecol., 27(2), 525-531. DOI: 10.13287/j.1001-9332.201602.019. 
[26] Huuskonen, J. and Oksanen, T., 2018, "Soil sampling with drones and augmented reality in precision agriculture,” Comput. Electron. Agric., 154, 25-35. DOI: 10.1016/j.compag.2018.08.039.

[27] Mazzoleni, M., Paron, P., Reali, A., Juizo, D., Manane, J. and Brandimarte, L., 2020, “Testing UAV-derived topography for hydraulic modelling in a tropical environment," Nat. Hazards, 103(1), 139-163. DOI: 10.1007/s11069-020-03963-4.

[28] Kacprzak, M. and Rotchimmel, K., 2016, "Creating photogrammetry products with photos acquired by array of non-metric cameras,” Trans. Inst. Aviat., 243(2), 120-129, (in Polish).

DOI: $10.5604 / 05096669.1205266$.

[29] Gitelson, A. A. and Merzlyak, M. N., 1998, "Remote sensing of chlorophyll concentration in higher plant leaves," Adv. Sp. Res., 22(5), 689-692. DOI: 10.1016/S0273-1177(97)01133-2.

[30] Lu, F., Sun, Y., and Hou, F., 2020, "Using UAV visible images to estimate the soil moisture of steppe," Water (Switzerland), 12(9), 2334-2351. DOI: 10.3390/W12092334.

[31] Jasiewicz, J., Zwoliński, Zb., Mitasova, H., Hengl, T. (Eds.), 2015, Geomorphometry for Geosciences, Bogucki Wydawnictwo Naukowe, Adam Mickiewicz University in Poznań - Institute of Geoecology and Geoinformation.

[32] Buters, T., Belton, D. and Cross, A., 2019, "Seed and Seedling Detection Using Unmanned Aerial Vehicles and Automated Image Classification in the Monitoring of Ecological Recovery," Drones, 3(3), 53-69. DOI: 10.3390/drones3030053.

[33] Wójtowicz, A. Wójtowicz, M. and Piekarczyk, J., 2016, "Application of remote sensing methods in agriculture," CBCS, 11(1), 31-50.

[34] Al-Gaadi, K. A. et al., 2016, "Prediction of potato crop yield using precision agriculture techniques," PLoS One, 11(9). DOI: 10.1371/journal.pone.0162219.

[35] Kotlarz, J., Nasiłowska, S., Rotchimmel, K., Kubiak, K. and Kacprzak, M., 2018, “Species Diversity of Oak Stands and Its Significance for Drought Resistance," Forests, 9(3), 126-148.

DOI: $10.3390 /$ f9030126.

[36] Chmielewski, S., Bochniak, A., Natapov, A. and Wezyk, P., 2020, "Introducing GEOBIA to landscape imageability assessment: A multi-temporal case study of the nature reserve 'Kozki', Poland," Remote Sens., 12(17), 2792-2817. DOI: 10.3390/RS12172792.

[37] Jeihouni, M., Alavipanah, S. K., Toomanian, A. and Jafarzadeh, A. A., 2020, "Digital mapping of soil moisture retention properties using solely satellite-based data and data mining techniques," J. Hydrol., 585, Article ID 124786. DOI: 10.1016/j.jhydrol.2020.124786.

\section{SZACOWANIE WILGOTNOŚCI GLEBY ZA POMOCA WSKAŹNIKÓW TELEDETEKCYJNYCH W ZAKRESIE SPEKTRALNYM 0,4-2,5 MM}

\footnotetext{
Abstrakt

Zawartość wody w glebie (SMC) jest ważnym elementem środowiska wpływającym na dostępność wody dla roślin, parametry atmosferyczne, a jej monitorowanie jest istotne w prognostyce powodzi lub susz a także modelowaniu pogody i klimatu. Optyczne metody pomiaru wilgotności gleby wykorzystują analizę odbicia spektralnego w zakresie od 350 do $2500 \mathrm{~nm}$. Uważa się, że teledetekcja jest skutecznym narzędziem monitorowania parametrów gleby na dużych obszarach i jest bardziej opłacalna w porównaniu z pomiarami in situ. Celem pracy jest ocena SMC gleby niepokrytej/skąpo pokrytej roślinnością na podstawie danych hiperspektralnych ze spektrometru polowego ASD FieldSpec 4 Hi-Res poprzez wyznaczenie wskaźników teledetekcji i wizualizacji na podstawie danych wielospektralnych uzyskanych
} 
z UAV. Pomiary teledetekcyjne zostały zweryfikowane na podstawie pomiarów wilgotności w terenie za pomocą miernika wilgotności HH2 z sondą Thete Probe ML3. Silną korelację między danymi naziemnymi i teledetekcyjnymi zaobserwowano dla 7 z 11 wybranych wskaźników, a wartości współczynników determinacji $\mathrm{R}^{2}$ wahały się w granicach $67 \%-87 \%$. Najlepsze wyniki uzyskano dla indeksu NINSON o wartościach współczynników determinacji 87\% a także dla indeksu NSMI 83,5\% i NINSOL 81,7\%. Dane z teledetekcji hiper- i multispektralnej dotyczące wilgotności niepokrytej/skąpo pokrytej roślinnością gleby mają wielką wartość, ponieważ zapewniają dobrą czasową i przestrzenną rozdzielczość rozkładu wilgotności gleby na obszarach lokalnych co jest istotne dla monitoringu i prognozowania lokalnych zmian klimatu.

Słowa kluczowe: wilgotność gleby, teledetekcja, dane hiperspektralne, gleba, UAV. 